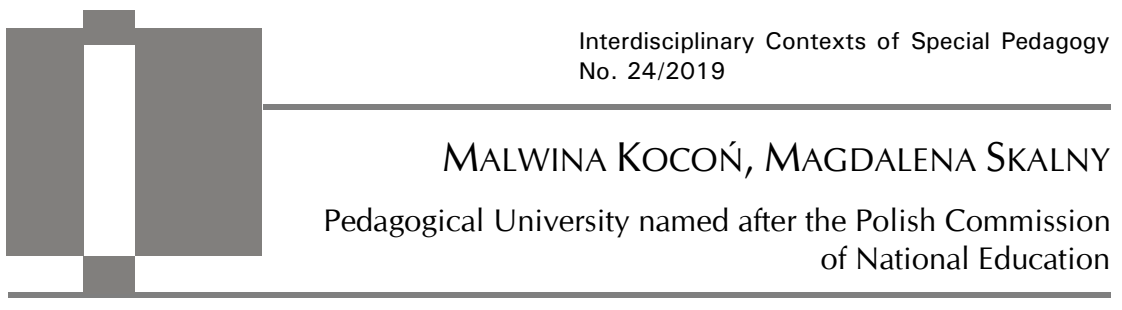

\title{
Stereotypes about the deaf and sign language in the thinking of special needs education students
}

\begin{abstract}
Malwina Kocon, Magdalena Skalny, Stereotypes about the deaf and sign language in the thinking of special needs education students. Interdisciplinary Contexts of Special Pedagogy, no. 24, Poznań 2019. Pp. 109-126. Adam Mickiewicz University Press. ISSN 2300-391X. DOI: https://doi.org/10.14746/ikps.2019.24.06

The article discusses the problems of deaf people, Polish sign language as well as Signed Polish (Manually-Coded Polish) in the context of stereotypes held by first year students of special needs education. The analysis of the results of empirical research indicates which of the stereotypes concerning deaf and sign language mentioned in the study are present in the thinking of the social group covered by the research and the frequency of their occurrence. It presents and explains terminological aspects regarding stereotypes and proposes postulates to eliminate negative stereotyping.
\end{abstract}

KEY WORDS: stereotypes, d/Deaf, sign language, Polish Sign Language, Signed Polish/ Manually-Coded Polish

\section{Foreword}

Currently, the problem of disability in special needs education is perceived in the emancipatory paradigm, where persons with various disabilities are presented in their socio-cultural and not only 
individualistic contexts ${ }^{1}$. A special group of persons with disabilities who opposes being treated as disabled persons and who, from the sociolinguistic perspective, is in the linguistic and cultural minority, are the Deaf. The term "Deaf" with capital D relates to persons who were born deaf or lost their hearing in early childhood and the Polish Sign Language (PSL) is their first or preferred language of communication. This spelling convention is currently used in deaf education, also in the literature of other languages (e.g. the English deaf/Deaf) ${ }^{2}$. The basic criterion of cultural distinctiveness and the source of the Deaf identity is deafness and the visual spatial language, such as the PSL ${ }^{3}$. However, the community of persons with hearing impairment is heterogeneous. This means that there are both Deaf persons, who identify themselves with the linguistic and cultural minority and the deaf (with small d), whose hearing loss is usually deep, but who have integrated themselves with the community of hearing persons ${ }^{4}$.

Among persons with disabilities, the Deaf are a separate group who, for the sake of emancipation, isolate themselves from the hearing society, strongly marking the borders of their autonomy. The causes influencing the development of the hermetic community of the Deaf are believed to be, among other things, their being perceived through the prism of disability ${ }^{5}$. Many persons who com-

${ }^{1}$ A. Krause, Niepetnosprawność - Inny w paradygmacie humanistycznym, Niepetnosprawność. Dyskursy pedagogiki specjalnej, vol. 4, no. 4, Wydawnictwo Uniwersytetu Gdańskiego, Gdańsk 2010, p. 111-121.

2 P. Rutkowski, M. Czajkowska-Kisil, O kategorii zaimka osobowego w polskim języku migowym (PJM), "LingVaria” no. 1(9) Rok V, 2010, p. 65-78.

${ }^{3}$ P. Tomaszewski, K. Kotowska, P. Krzysztofiak, Paradygmaty tożsamości u g/Gtuchych: przegląd wybranych koncepcji, [in:] E. Woźnicka (ed.), Edukacja niestyszacych - wczoraj, dziś i jutro, Wydawnictwo Akademii Humanistyczno-Ekonomicznej w Łodzi, Łódź 2017, p. 111-155.

${ }^{4}$ U. Bartnikowska, Głuchota - mniejszość językowa, kulturowa, pogranicze..., czyli społeczny kontekst badania zjawisk związanych z uszkodzeniem stuchu, Niepetnosprawność. Dyskursy pedagogiki specjalnej, volt. 4, no. 4, Wydawnictwo Uniwersytetu Gdańskiego, Gdańsk 2010, p. 27-41.

${ }^{5}$ D. Podgórska-Jachnik, Głusi Emancypacje, Wydawnictwo Naukowe Wyższej Szkoły Pedagogicznej w Łodzi, Łódź 2013. 
prise the community of hearing persons describes the $d /$ Deaf as handicapped, invalids. They claim that heir social functioning should be stimulated and that they should be freed from isolation. In order to achieve that goal, some generally accepted means of communication should be imposed and a d/Deaf person should transform into a hearing person by learning their way of life and the functioning of the rest of the society ${ }^{6}$.

Lack or limited knowledge of the d/Deaf persons community, their language, culture and way of functioning, medical understanding of deafness and domination of the biological paradigm that focuses on the disability as a defect ${ }^{7}$ have a direct effect on the attitudes of hearing persons towards d/Deaf persons, this way contributing to the development and multiplication of stereotypes.

\section{Terminology used}

Andrzej Paweł Wejland ${ }^{8}$ found in the literature more than 260 definitions and less formal characteristics of the concept of stereotype. Jan Błuszkowski, on the other hand, claims that the stereotype is a polysemic term and its definitions are not exhaustive. Depending on the particular study area, they adopt relevant content. The concepts of stereotypes are explored by sociology, social psychology, linguistics, logic and cognitive theory ${ }^{9}$.

Ida Kurcz presents the sociologic approach:

sociologists focus on the more global, socio-cultural factors that influence the development of stereotypes and the way that stereotypes con-

${ }^{6}$ M. Wójcik, Wybrane aspekty społecznego funkcjonowania młodzieży niestyszacej i stabostyszacej, Oficyna Wydawnicza „Impuls”, Kraków 2008.

${ }^{7}$ A. Krause, op. cit., p. 111-121.

8 A.P. Wejland, Obrazy grup społecznych. Studium metodologiczne, PAN, Warszawa 1991, p. 211.

9 J. Błuszkowski, Stereotypy narodowe w świadomości Polaków, Dom Wydawniczy Elipsa, Warszawa 2003. 
cerning those who are "other" in one way or another function in social behavior ${ }^{10}$.

Sociologists are mainly interested in differences and similarities between nations, social groups and collectivities, rather than between individuals.

In the psychosocial model, on the other hand, stereotypes are interpreted as "a popular mental images the object of which may be any collectivity, even that with respect to which cultural resources did not have enough time to form"11. In this model, an individual may be either a medium or co-author of a stereotype that has formed in culture.

Uta Quasthoff's definition contains a logical and a linguistic aspect. According to her,

the stereotype is a verbal expression of a conviction addressed to social groups of individuals who are their members. In the logical aspect, it is a judgment of specific properties (groundlessly simplistic or generalizing, associated with an emotional and evaluating trend and attributing or refusing certain features and behavior to a given class of persons). In the linguistic aspect, it is a sentence ${ }^{12}$.

Due to the properties of the stereotype, researchers propose many definitions, since every concept focuses on its specific aspect. It can be positive or negative - half of the definitions assume that the stereotype is "bad" as it accumulates generalized data or the generalization is untrue or distorted, or it is too stiff, or contains various combinations of negative features ${ }^{13}$. Positive stereotypes, on

${ }^{10}$ I. Kurcz, Stereotypy, prototypy i procesy kategoryzacji, [in:] Kolokwia psychologiczne. Stereotypy $i$ uprzedzenia, ed. Z. Chlewiński, I. Kurcz, Instytut Psychologii PAN, Warszawa 1992, p. 10.

11 Z. Bokszański, Stereotypy a kultura, „Leopoldium”, Wrocław 1997, p. 33.

12 J. Raszke, Wobec bezrobocia - opinie i stereotypy, Wydawnictwo Śląsk, Katowice 1999, p. 66-67.

13 B. Wojciszke, Psychologia społeczna. System poznawczy i procesy spostrzegania ludzi, UG, Gdańsk 1983. 
the other hand, associate positive or desired features with a certain group ${ }^{14}$.

In 1954, Gordon Allport proposed a definition of stereotyping that did not evaluate either stereotypes or the people who use them. According to him, "the stereotype is a magnified conviction associated with a specific category"15.

All the above definitions and types of stereotypes are individually interpreted by different authors. The article focuses on the stereotypes that concern the $\mathrm{d} /$ Deaf and manual forms of communication. The hearing society, simply speaking, depreciates this group and creates its untrue image.

\section{Stereotypes concerning the $d /$ Deaf}

The consequences of stereotypical treatment of the $d$ /Deaf by hearing persons contribute to the formation of social barriers and a distance that is reflected in manifesting hostile behavior and/or distrust. Prejudices that concern the $\mathrm{d} /$ Deaf have a major impact on the formation of their self-image, lowered self-esteem, sense of security or sense of agency. The deaf are often confronted with the problem of identifying their own social belonging (the world of the Deaf/hearing), and stereotypical treatment inhibits adaptation processes and hinders acceptance of disability.

Selected myths and stereotypes that function in social awareness concerning the $\mathrm{d} /$ Deaf and arguments that constitute the reality and refute the untrue image of those persons are presented below:

Stereotype 1: Treating all the deaf/Deaf as the same persons in every respect. Regarding them to be weak, less worthy, incapable ${ }^{16}$.

14 T.D. Nelson, Psychologia uprzedzeń, GWP, Gdańsk 2003.

${ }^{15}$ Ibidem, p. 25-26.

${ }^{16}$ M. Wójcik, op. cit., p. 46. 
Fact: As has already been mentioned, the community of persons with hearing damage is not homogeneous. Many of them live in between two worlds: the world of the hearing and the world of the Deaf. Some of them have found their place among the hearing. Some of them - sometimes unsuccessfully - look for their place and identity in the society. They differ not only in terms of different hearing damages and ways of communication (phonetic and/or sign) but also in everything that distinguishes people from one another all over the world: demographic, social and individual features ${ }^{17}$.

Stereotype 2: All the d/Deaf use the sign language or the conviction that all can lip read. The stereotype and conviction that they cannot talk ${ }^{18}$.

Fact: The deaf or hard of hearing may communicate in many different ways: using the sing language. They can write (using the traditional pen and paper, or the latest technologies - mainly young and middle-aged persons: text messages, e-mails, social websites, etc.). They can talk (many d/Deaf and hard of hearing persons talk, although their speech may have distorted articulation) ${ }^{19}$. Their acoustic reception may be improved by hearing aids, implants or peripheral devices, which involves not so much pure lip reading but visual andauditory reception, and, in the case of other manual forms of communication, e.g. the sign language, visual, auditory and kinesthetic reception. Thus, lip reading is one of the elements of the complex communication of the d/Deaf. In the case of children with hearing impairment (according to the classification of the depth and scope of hearing loss according to to the International

17 Z. Teper-Solorz, Głusi - na marginesie "świata styszacych”, "Uniwersyteckie Czasopismo Socjologiczne" no. 14, Wydawnictwo Uniwersytetu Kardynała Stefana Wyszyńskiego, Warszawa 2016, p. 40, after: U. Bartnikowska, Sytuacja społeczna i rodzinna styszacych dzieci niestyszących rodziców, Wydawnictwo Edukacyjne Akapit, Toruń 2010, p. 56-57, 64.

18 M. Wójcik, op. cit., p. 46.

19 http:/ / glusiwpracy.dobrekadry.pl/pracagluchych/Sytuacja_i_mozliwosci_ak tywizacji_Gluchych.pdf [accessed on: 24.03.2018]. 
Bureau of Audiophonology ${ }^{20}$ moderate hearing loss - from 41 to $70 \mathrm{~dB}$ ), lip reading only supports hearing and rarely reaches the level when it is possible to recognize speech only visually. In the case of deaf children (significant hearing loss, i.e. 71-90 dB or deep above $91 \mathrm{~dB}$ ), lip reading should be formed and developed the same as active speech ${ }^{21}$.

Stereotype 3: In the community of hearing persons, there is the popular stereotype that all the deaf are "Stone deaf", i.e. they do not hear anything.

Fact: This is not quite true. Only $2-4 \%$ of persons with hearing impairment do not react to very strong sounds, but most of them can hear loud sound signals in the environment ${ }^{22}$.

Stereotype 4: Having a hearing aid implant means that the hearing has been restored.

Fact: Hearing aids and implants do not restore hearing. The hearing aid stimulates hearing by intensifying the sounds in the environment, while the implant, like the cochlear implant, transforms sounds to electrical impulses and sends them directly to the hearing nerves. When a d/Deaf person switches off or removes such appliance, he or she will still be deaf.

The undeniable advantage of using hearing appliances is socalled two-channel speech reception: visual and audial, which facilitates lip reading 23 . Each person is a specific combination of traits and skills, so it is not possible for every patient to achieve full identification and discrimination of the surrounding sounds, including the sounds of speech. Patient rehabilitation is not always successful

${ }^{20}$ H. Skarżyński, M. Mueller-Malesińska, W. Wojnarowska, Klasyfikacje zaburzeń stuchu, Audiofonologia, vol. 10, Warszawa 1997, p. 55-57.

21 B. Szczepankowski, Odczytywanie mowy $z$ ust $u$ dzieci $z$ uszkodzonym stuchem, http://www.reedukacja.pl/default.aspx?action=view\&item $=530$ [accessed on: 24.03.2018].

22 B. Szczepankowski, Niestyszący - Gtusi - Gtuchoniemi, WSiP, Warszawa 1999, p. 169.

23 A. Korzon, Implanty ślimakowe w rehabilitacji osób z uszkodzonym narządem stuchu, „Niepełnosprawność” 2010, no. 4, p. 13. 
and it is not always possible to achieve a satisfactory hearing threshold and the ability to use the verbal speech in full extent ${ }^{24}$.

Stereotype 5: Communication difficulties may contribute to the development of myths about the sign language - it is treated as a set of gestures that cannot express abstract ideas and, because of not having grammar, it is not regarded as a language ${ }^{25}$. Myths and prejudices concerning the sign language include, among other things: determining a person's cognitive abilities and thinking through the prism of the sign language, perceiving the sign language as a primitive form of communication and undermining its value, learning the speech is hindered by early acquisition of the sign language, preventing the development of the sign language contributes to better education in spoken language ${ }^{26}$.

Fact: Due to the limited space, the authors only want to signal the presence of the above myths and stereotypes.

Those who would like to find out more about the problem are recommended to read Piotr Tomaszewski ${ }^{27}$.

This text presents an analysis of the results of research concerning selected stereotypical ways of thinking about the d/Deaf, PSL and Manually Coded Polish (MCP).

\section{Methodological assumptions of the research}

The main goal of the research was to identify which of the selected stereotypes function among first year special needs education

${ }^{24}$ B. Kasica, K. Kasica-Bańkowska, Diagnoza i etapy rehabilitacji pacjenta po wszczepieniu implantu ślimakowego, Logopedia Silesiana, no. 2, Wydawnictwo Uniwersytetu Śląskiego, Katowice 2013, p. 167.

25 D. Bouvet, Mowa dziecka - wychowanie dwujęzykowe dziecka niestyszącego, WSiP, Warszawa 1996, p. 134-142.

26 S. Prillwitz, Język, komunikacja i zdolności poznawcze niestyszaccych, WSiP, Warszawa 1996, p. 293.

27 P. Tomaszewski, Funkcjonowanie jezzykowo-poznawcze u dzieci głuchych, [in:] Edukacja głuchych, Materiaty konferencyjne, ed. M. Sak, Rzecznik Praw Obywatelskich, Warszawa 2014. 
students and to what extent these students use the stereotypes in the context of the $\mathrm{d} /$ Deaf and manual communication systems, i.e. the PSL and SPL.

The empirical data used for this purpose were collected by means of the diagnostic analysis method, and the tool was a survey questionnaire. The tool was developed partly based on selected social myths concerning the deaf according to Włodzimierz Pietrzak $^{28}$ and stereotypes about the PSL identified by Mariusz Sak ${ }^{29}$ The survey consisted of 16 close-ended questions, which the respondent students were to answer "true" or "false".

The following detailed questions were asked with respect to the research problem:

a) What stereotypes about the $d$ /Deaf function among special needs education students?

b) What stereotypes concerning manual communication systems exists in the thinking of special needs education students?

c) Which of the stereotypes are the most often mentioned by special needs education students?

The research conducted in 2016 covered a group of 84 1st year students of special needs education at the Pedagogical University of Krakow. The vast majority of the respondents (99\%) were women. In the respondent group of first year students, the average age was 19 years.

\section{Results of own research}

The questions in the survey were divided into two categories. The first category concerned stereotypes about the d/Deaf, and the second - stereotypes about manual communication systems, both

28 B. Szczepankowski, Wyrównywanie szans osób niestyszacych - optymalizacja komunikacji językowej, Wydawnictwo Uczelniane WSRP, Siedlce 1998, p. 41-47.

${ }^{29}$ M. Sak, Wczesne zaangażowanie: skrypt dla stuchaczy kursu Gtuchy jako wzór, Polski Związek Głuchych, Łódź 2012, p. 58-59. 
the Polish sign language and the manually coded Polish. The results of the collected empirical material concerning stereotypes about the $\mathrm{d} /$ Deaf are presented in table 1 .

Table 1. Stereotypes about the d/Deaf among respondents

\begin{tabular}{|r|l|r|r|r|r|r|r|}
\hline \multirow{2}{*}{ No. Statement } & \multicolumn{2}{|c|}{ True } & \multicolumn{2}{|c|}{ False } & \multicolumn{2}{|c|}{ No answer } \\
\cline { 3 - 9 } & & $\mathrm{N}$ & $\%$ & $\mathrm{~N}$ & $\%$ & $\mathrm{~N}$ & $\%$ \\
\hline 1. & $\begin{array}{l}\text { The deaf have lower IQ than hearing } \\
\text { persons }\end{array}$ & 1 & 1.2 & 82 & 97.6 & 1 & 1.2 \\
\hline 2. & All the deaf use the sign language & 31 & 36.9 & 53 & 63.1 & 0 & 0 \\
\hline 3. & $\begin{array}{l}\text { All the deaf want to be cured and want } \\
\text { to hear }\end{array}$ & 30 & 35.7 & 52. & 61.9 & 2 & 2.4 \\
\hline 4. & All the deaf can lip read & 19 & 22.6 & 65 & 77.4 & 0 & 0 \\
\hline 5. & The deaf do not mind noise & 21 & 25 & 57 & 67.9 & 6 & 7.1 \\
\hline 6. & $\begin{array}{l}\text { The dead and the deaf-mute are synon- } \\
\text { ymous }\end{array}$ & 10 & 11.9 & 71 & 84.5 & 3 & 3.6 \\
\hline 7. & Hearing aid and implants restore hearing & 10 & 11.9 & 71 & 84.5 & 3 & 3.6 \\
\hline 8. & $\begin{array}{l}\text { Once a deaf receives "hearing" support, } \\
\text { everything develops as in hearing chil- } \\
\text { dren }\end{array}$ & & & & & & \\
\hline 9. & All the deaf are "stone deaf" & 1 & 1.2 & 81 & 96.4 & 2 & 2.4 \\
\hline 10. & Deaf parents always have deaf children & 5 & 5.9 & 78 & 92.9 & 1 & 1.2 \\
\hline
\end{tabular}

Source: Results of own research

An analysis of the data presented in table 1 shows that the most popular stereotype $(38.1 \%)$ among the respondents is that once a deaf child receives a "hearing" support in the form of an implant, everything develops as in hearing children. Meanwhile, as one of the authors, Malwina Kocon notes in her paper $^{30}$, the sole fact

${ }^{30}$ M. Kocoń, Stereotypy myślowe dotyczace osób niestyszacych i języka migowego, [in:] Teoria i praktyka oddziatywań profilaktyczno-wspierających rozwój osób z niepetnosprawnością: konteksty indywidualne i środowiskowe, T. 4.2., ed. K. Parys, M. Pasteczka, J. Sikorski, Wydawnictwo Uniwersytetu Pedagogicznego, Kraków 2017, p. 136-149. 
of providing a deaf child with a hearing aid or implant does not improve the quality of sounds received from the environment, speaking or understanding speech. In order to achieve an adequately high level of the above functions and competencies, a child with a hearing implant must undergo rehabilitation, which is a long and laborious process that does not always yield the expected or satisfactory effects.

The second most frequent (36.9\%) stereotype selected by the respondents is the myth that all the deaf persons use sign language. It should be noted here that the deaf community is not homogeneous when it comes to communication. There are persons among the deaf for whom the PSL is the first language. This is the case with deaf children of Deaf parents and hearing children of Deaf parents (so-called CODA, Children of Deaf Adult). Deaf parents most often communicate with their children in the sign language, which they naturally learn as their first language. It also happens that PSL is a foreign language to the deaf - in most cases, this concerns the deaf children of hearing parents who do not use the sign language or deaf adults who use the Polish language in their everyday communication.

Another popular stereotype (35.7\%) in the analyzed empirical material is that all the $d$ /Deaf persons want to be cured of deafness. The fact is, however, that the Deaf do not regard their deafness as a hearing pathology or disability. P. Tomaszewski writes that "The Deaf do not necessarily feel disabled and they may treat their deafness not as a bad experience or handicap, but as a unique condition that constitutes for them a key to their own identity and is a reason for pride" 31 .

It seems optimistic that a vast majority of respondents $(97.6 \%)$ do not agree with the stereotype that the $\mathrm{d} /$ Deaf have lower intelli-

31 P. Tomaszewski, Ksztattowanie kompetencji socjokulturowej w nauczaniu polskiego języka migowego, [in:] Kulturowe i społeczne aspekty niepetnosprawności, ed. P. Tomaszewski, K. Bargiel-Matusiewicz, E. Pisula, Wydawnictwo UW, Warszawa 2015, p. 22. 
gence quotient than the hearing society. This stereotype may have developed in the society in the 1950s, when, according to Marc Marschark and Loes Wauters ${ }^{32}$ the first research on the cognitive functioning of deaf children and adults was conducted. Then, the deaf were considered to have a lower level of intelligence. Nonetheless, the relatively low results in terms of the IQ of the deaf were not due, as it was assumed, to the etiology of deafness, lack of of early rehabilitation or not sufficiently mastering the phonetic language, but mainly due to methodological negligence during research on the cognitive development of deaf children. This thinking changed to the advantage of the $d /$ Deaf and in the 1970s, it was assumed that the conclusions made on the basis of research on the intelligence of the deaf were unsubstantiated ${ }^{33}$.

The respondents are highly aware (96.4\%) that the statement that all deaf are "stone deaf" is false.

Also the responses to the statement that $d /$ Deaf parents always have deaf children were interesting. A vast majority of responding students $(92.9 \%)$ consider this statement to be untrue. In fact, as Marek Świdziński ${ }^{34}$ and Piotr Tomaszewski ${ }^{35}$ report, most deaf children $(90 \%)$ are born in hearing families. The other $10 \%$ of deaf children have $\mathrm{d} /$ Deaf parents. This is also confirmed by Małgorzata Czajkowska-Kisil and Agnieszka Laskowska-Klimczewska ${ }^{36}$. It is

32 M. Marschark, L. Wauters, Cognitive functioning in deaf adults and children, [in:] The Oxford Handbook of Deaf Studies, Language, and Education, ed. M. Marschark, P.E. Spencer, Volume 1 (2 ed.), Oxford University Press, New York 2011, p. 487-499.

33 P. Tomaszewski, Funkcjonowanie jezykowo-poznawcze..., p. 14-31.

${ }^{34}$ M. Świdziński, Wprowadzenie, [in:] Sytuacja osób głuchych w Polsce, Raport zespołu ds. g/Głuchych przy Rzeczniku Praw Obywatelskich, ed. M. Świdziński, Biuro Rzecznika Praw Obywatelskich, Warszawa 2014, p. 8-12.

35 P. Tomaszewski, Mówić czy migać? Prawo dziecka głuchego do wychowania dwujęzycznego, [in:] Społeczeństwo równych szans. Tendencje i kierunki zmian, ed. D. Gorajewska, Stowarzyszenie Przyjaciół Integracji, Warszawa 2005, p. 113-124.

36 M. Czajkowska-Kisil, A. Laskowska-Klimczewska, CODA: Inność nierozpoznana, [in:] Sytuacja osób głuchych w Polsce. Raport zespotu ds. g/Głuchych przy Rzeczniku Praw Obywatelskich, red. M. Świdziński, Warszawa 2014, p. 117. 
worth noting that the majority of $d$ /Deaf parents have hearing children ${ }^{37}$.

The other analyzed stereotype concerned manual communication methods, both PSL and MCP. Data collected on the basis of empirical material are presented in table 2.

Table 2. Respondents' stereotypes concerning the sign language (PSL and MCP)

\begin{tabular}{|c|l|r|r|r|r|r|r|r|}
\hline \multirow{2}{*}{ No. } & \multicolumn{2}{|c|}{ Statement } & \multicolumn{2}{c|}{ True } & \multicolumn{2}{c|}{ False } & \multicolumn{2}{c|}{ No answer } \\
\cline { 3 - 9 } & & $\mathrm{N}$ & $\%$ & $\mathrm{~N}$ & $\%$ & $\mathrm{~N}$ & $\%$ \\
\hline 1. & PSL is the natural language of the deaf & 32 & 38.1 & 19 & 22.6 & 33 & 39.3 \\
\hline 2. & PSL is a sub-code of the Polish language & 37 & 44.0 & 16 & 19.0 & 31 & 37.0 \\
\hline 3. & $\begin{array}{l}\text { PSL makes it more difficult to learn to } \\
\text { speak and understand Polish language }\end{array}$ & 6 & 7.1 & 46 & 54.8 & 32 & 38.1 \\
\hline 4. & PSL was created by hearing persons & 35 & 41.7 & 15 & 17.8 & 34 & 40.5 \\
\hline 5. & $\begin{array}{l}\text { Sign language is universal - it is the } \\
\text { same everywhere }\end{array}$ & 47 & 56.0 & 34 & 40.5 & 3 & 3.5 \\
\hline 6. & $\begin{array}{l}\text { Sign language is the only language used } \\
\text { by the deaf }\end{array}$ & 26 & 31.0 & 54 & 64.3 & 4 & 4.7 \\
\hline
\end{tabular}

Source: Results of own research

Most respondents (56\%) believe that the sign language is universal. The opinion that the sign language is universal, i.e. that sign languages are similar all over the world is untrue. In fact, respective sign languages are as different from one another as phonetic languages, which is confirmed by the research conducted by Heleen Bos and Trude Schermer ${ }^{38}$. The conviction that the sign language is

37 B.L. Mallory, H.W. Zingle, J.D. Schein, Intergenerational Communication Modes In Deaf-Parented Families, “Sign Language Studies” 1993, no. 78, p. 73-92.

${ }^{38}$ H. Bos, T. Schermer, Sign language research. Proceedings the 4th European Congress on sign language research, Munich, September 1-3. Hamburg: Signum, 1995, after: P. Tomaszewski, Mity o Polskim Jezzyku Migowym, „Nauczyciel w Świecie Ciszy" 2006, no. 8, p. 2-11. 
universal may be due to the fact that the d/Deaf using different sign languages find it easier to communicate with one another than hearing persons who use different phonetic languages. This is due to certain grammatical universalities in sign languages, which are based on facial mimicry, natural gestures, body language and elements of pantomime ${ }^{39}$. It is worth noting that there us an international system of communication called the International Sign, used by the $d$ /Deaf on the international arena (e.g. during international conferences, Miss \& Mister competitions, Deaflympics, etc.) and at meetings attended by persons from different parts of the world ${ }^{40}$.

Another popular myth among the responding students $(44 \%)$ is that the PSL is a sub-code of the Polish language. Sylwia Łozińska notes: "The PSL develop (...) independently of the phonetic Polish language, based on the communicational needs of the deaf themselves, without the interference of the hearing community" 41 . A visual and spatial sub-code of the Polish language is the MCP, which means that it uses both Polish grammar and sign language symbols. It needs to be highlighted not only because the stereotype is popular but also because many authors of academic publications on deaf education do not distinguish between the PSL and the MCP, which is reflected in the social perception of the $d /$ Deaf in the hearing society ${ }^{42}$.

Of all the myths and stereotypes listed in the table the most disputable was opinion no. 4: "PSL was created by hearing persons", causing the highest disagreement between the respondent group. Nearly the same number of respondents agreed with this statement

39 Ibidem.

40 https://edl.ecml.at/Facts/FAQsonsignlanguage/tabid/2741/language/pl-PL/ Default.aspx [accessed on: 30.01.2018].

41 S. Łozińska, Gramatyczne funkcje ruchu w polskim języku migowym (PJM), [in:] Ruch w języku - język w ruchu, ed. K. Lisczyk-Kubina, M. Maciołek, published by Uniwersytet Śląski, GNOME, Katowice 2012, p. 90.

42 E. Moroń, Konceptualizacja języka migowego w edukacji niestyszących - spojrzenie krytyczne, [in:] Edukacja niesłyszących, ed. E. Twardowska, M. Kowalska, Łódź 2011, 157-169. 
(35 persons, which is $41.7 \%$ ) and had no opinion (34 persons, which is $40.5 \%)$. An equally high percentage of respondents had no opinion on statement 1: "PSL is the natural language of the deaf". 32 persons, which constitutes $38.1 \%$, agreed with this statement, which 33 persons, which constitutes $39.3 \%$, gave no answer.

\section{Conclusions and recommendations}

Analysis of the empirical material based on the constructed tools revealed the presence of stereotypes about the d/Deaf, PSL and MCP in the awareness of first-year special needs education students who were involved in the research.

The results of the research show that some of the stereotypes presented in the research are not shared by the students, but also that knowledge about the d/Deaf and about the PSL and MCP is incomplete and based on stereotypes, which may (though not necessarily) contribute to biased multiplication and dissemination of untrue slogans. Also, the research was conducted among first year students and there still is hope that, as their knowledge develops and deepens in the course of studies, their stereotypical thinking will be fully or partly transformed.

In the light of the results of the research, the authors would like to note that the goal of developed societies is to deepen humanitarianism, in the broad meaning of the term and, at the same time, to reduce audism. Such measures should be based on awareness raising and broadening knowledge about the $\mathrm{d} /$ Deaf, their culture and language, which helps reduce the stereotypization phenomenon. They include, among other things:

- Organization of meetings with the deaf and getting to know their environment through immersion in it,

- Organization of visits at the Polish Association of the Deaf in order to get to know the people who work with the death and their experiences with and opinions about them; 
- Acquainting students with educational methods and strategies used in the deaf education system,

- Participating in cultural educational and integration events,

- Acquainting students with the literature, cinematography and programmes about the deaf and sign language,

- Organizing lectures on stereotypes and prejudices,

- Presenting the culture of the deaf,

- Acquainting students with a linguistic description of the sign language.

\section{Bibliography}

Bartnikowska U., Głuchota - mniejszość językowa, kulturowa, pogranicze..., czyli społeczny kontekst badania zjawisk zwiąanych z uszkodzeniem stuchu, Niepetnosprawność. Dyskursy pedagogiki specjalnej, vol. 4, no. 4, Wydawnictwo Uniwersytetu Gdańskiego, Gdańsk 2010, p. 27-41.

Bos H., Schermre T., Sign language research. Proceedings od the 4th European Congress on sign language research, Muniach, Sptemper 1-3, Signum Hamburg 1995.

Bouvet D., Mowa dziecka - wychowanie dwujezzykowe dziecka niestyszacego, WSiP, Warszawa 1996.

Błuszkowski J., Stereotypy narodowe w świadomości Polaków, Dom Wydawniczy Elipsa, Warszawa 2003.

Bokszański Z., Stereotypy a kultura, „Leopoldium”, Wrocław 1997.

Czajkowska-Kisil M., Laskowska-Klimczewska A., CODA: Inność nierozpoznana, [in:] Sytuacja osób głuchych w Polsce. Raport zespołu ds. g/Głuchych przy Rzeczniku Praw Obywatelskich, ed. M. Świdziński, Warszawa 2014.

Kasica B., Kasica-Bańkowska K., Diagnoza i etapy rehabilitacji pacjenta po wszczepieniu implantu ślimakowego, Logopedia Silesiana, no. 2, Wydawnictwo Uniwersytetu Śląskiego, Katowice 2013.

Kocoń M., Stereotypy myślowe dotyczące osób niestyszacych i języka migowego, [in:] Teoria i praktyka oddziatywań profilaktyczno-wspierających rozwój osób z niepełnosprawnościa: konteksty indywidualne i środowiskowe, Vol. 4.2., ed. K. Parys, M. Pasteczka, J. Sikorski, Wydawnictwo Uniwersytetu Pedagogicznego, Kraków 2017, p. 136-149.

Korzon A., Implanty ślimakowe w rehabilitacji osób z uszkodzonym narządem stuchu, „Niepełnosprawność” 2010, no. 4. 
Krause A., Niepetnosprawność - Inny w paradygmacie humanistycznym, Niepetnosprawność. Dyskursy pedagogiki specjalnej, vol. 4, no. 4, Wydawnictwo Uniwersytetu Gdańskiego. Gdańsk 2010.

Kurcz I., Stereotypy, prototypy i procesy kategoryzacji, [in:] Kolokwia psychologiczne. Stereotypy i uprzedzenia, ed. Z. Chlewiński, I. Kurcz, Instytut Psychologii PAN, Warszawa 1992.

Lane H., Maska dobroczynności. Deprecjacja spoteczności głuchych, translated by T. Gałkowski, J. Kobosko, Wydawnictwo Szkolne i Pedagogiczne, Warszawa 1996.

Łozińska S., Gramatyczne funkcje ruchu w polskim jezzyku migowym (PJM), [in:] Ruch $w$ jezzyku - jezzyk $w$ ruchu, ed. K. Lisczyk-Kubina, M. Maciołek, Uniwersytet Śląski, GNOME, Katowice 2012.

Mallory B.L., Zingle H.W., Schein J.D., Intergenerational Communication Modes In Deaf-Parented Families, "Sign Language Studies" 1993, no. 78, p. 73-92.

Marschark M., Wauters L., Cognitive functioning in deaf adults and children, [in:] The Oxford Handbook of Deaf Studies, Language, and Education, ed. M. Marschark, P.E. Spencer, Volume 1 (2 ed.), Oxford University Press, New York 2011, p. 487-499.

Moroń E., Konceptualizacja języka migowego w edukacji niestyszacych - spojrzenie krytyczne, [in:] Edukacja niestyszacych, ed. E. Twardowska, M. Kowalska, Łódź 2011, 157-169.

Nelson T.D., Psychologia uprzedzeń, GWP, Gdańsk 2003.

Podgórska-Jachnik D., Głusi Emancypacje, Wydawnictwo Naukowe Wyższej Szkoły Pedagogicznej w Łodzi, Łódź 2013.

Prillwitz S., Jezzk, komunikacja i zdolności poznawcze niestyszących, WSiP, Warszawa 1996.

Raszke J., Wobec bezrobocia - opinie i stereotypy, Wydawnictwo Śląsk, Katowice 1999.

Rutkowski P., Czajkowska-Kisil M., O kategorii zaimka osobowego w polskim jezyku migowym (PJM), „LingVaria” 2010, no. 1(9) Year V, p. 65-77.

Sak M., Wczesne zaangażowanie: skrypt dla stuchaczy kursu Głuchy jako wzór, Polski Związek Głuchych, Łódź 2012.

Skarżyński H., Mueller-Malesińska M., Wojnarowska W., Klasyfikacje zaburzeń stuchu, Audiofonologia, vol. 10, Warszawa 1997.

Szczepankowski B., Niestyszacy - Gtusi - Gtuchoniemi, WSiP, Warszawa 1999.

Szczepankowski B., Wyrównywanie szans osób niestyszacych - optymalizacja komunikacji jezzykowej, Wydawnictwo Uczelniane WSRP, Siedlce 1998.

Świdziński M., Wprowadzenie, [in:] Sytuacja osób głuchych w Polsce, Raport zespotu ds. g/Gtuchych przy Rzeczniku Praw Obywatelskich, ed. M. Świdziński, Biuro Rzecznika Praw Obywatelskich, Warszawa 2014, p. 8-12.

Teper-Solorz Z., Głusi - na marginesie „świata styszacych”, Uniwersyteckie Czasopismo Socjologiczne, no. 14, Wydawnictwo Uniwersytetu Kardynała Stefana Wyszyńskiego, Warszawa 2016. 
Tomaszewski P., Funkcjonowanie językowo-poznawcze u dzieci głuchych, [in:] Edukacja gluchych, Materiaty konferencyjne, red. M. Sak, Rzecznik Praw Obywatelskich, Warszawa, 2014, p. 14-31.

Tomaszewski P., Kotowska K., Krzysztofiak P., Paradygmaty tożsamości u g/Głuchych: przeglad wybranych koncepcji, [in:] Edukacja niestyszacych - wczoraj, dziś i jutro, red. E. Woźnicka, Wydawnictwo Akademii Humanistyczno-Ekonomicznej w Łodzi, Łódź 2017, p. 111-155.

Tomaszewski P., Kształtowanie kompetencji socjokulturowej w nauczaniu polskiego jezzyka migowego, [in:] Kulturowe i spoteczne aspekty niepetnosprawności, ed. P. Tomaszewski, K. Bargiel-Matusiewicz, E. Pisula, Wydawnictwo UW, Warszawa 2015, p. 21-40.

Tomaszewski P., Mity o Polskim Jezzyku Migowym, "Nauczyciel w Świecie Ciszy” 2006, no. 8, p. 2-11.

Tomaszewski P., Mówić czy migać? Prawo dziecka głuchego do wychowania dwujęzycznego, [in:] Spoteczeństwo równych szans. Tendencje i kierunki zmian, ed. D. Gorajewska, Stowarzyszenie Przyjaciół Integracji, Warszawa 2005, p. 113-124.

Wejland A.P., Obrazy grup społecznych. Studium metodologiczne, PAN, Warszawa 1991.

Wojciszke B., Psychologia spoleczna. System poznawczy i procesy spostrzegania ludzi, UG, Gdańsk 1983.

Wójcik M., Wybrane aspekty spotecznego funkcjonowania młodzieży niestyszącej i stabostyszącej, Oficyna Wydawnicza „Impuls”, Kraków 2008.

\section{Internet sources}

Szczepankowski B., Odczytywanie mowy z ust u dzieci z uszkodzonym stuchem, http:/ / www.reedukacja.pl/default.aspx?action=view\&item $=530$ [accessed on: 24.03.2018]. http://glusiwpracy.dobrekadry.pl/pracagluchych/Sytuacja_i_mozliwosci_aktywi zacji_Gluchych.pdf [accessed on: 24.03.2018].

https://edl.ecml.at/Facts/FAQsonsignlanguage/tabid/2741/language/pl-PL/De fault.aspx [accessed on: 30.01.2018]. 